\title{
Study of the development of prosumer microgeneration in the Siedlce subregion
}

\section{Zbigniew Cieszkowski}

\section{ABSTRACT}

The paper presents the results of research and analysis of the currently most popular renewable energy sector, i.e. microgeneration. It is developed at the lowest level of the entire cycle of generation, transmission, distribution and consumption of energy, i.e. at the level of its customers. It is an important component of civic energy, in which the existing consumer (private person, local government unit, business entity, etc.) also becomes an energy producer and an active partner of the energy sector in local energy management. It acts to improve the efficiency of energy use, thus obtaining certain financial, energy and environmental benefits.

The article presents the material results of RES energy use in the microgeneration of power and heat in the Siedlce subregion (52 municipalities - 16.5\% of all the municipalities of Mazovia Province). It allowed gaining practical experience allowing to extend the research to other subregions of the region. The influence of national legal conditions, statutory support system, planning and organizational activities of the self-government and the municipalities of Mazovia Province on the development of local microgeneration (on the municipal level) was investigated. Basic local conditions were analysed, i.e. economic (municipal incomes), technical (municipal energy profiles, conditions of distribution networks), construction and environmental. Numerous positive factors influencing the development of the sector were highlighted, but real limitations were also clearly indicated. The sources of information included basic legal acts of the national level, programming, planning and strategic documents of the regional and municipal level, data of the Central Statistical Office [GUS] and energy companies and information obtained from the survey conducted by the municipalities. There are no specialized and detailed publications on the practical results of the development of this energy sector at the Mazovian municipalities level. This article is intended to fill this gap. An author's attempt was made to determine the real place and role of this energy sector in achieving national RES targets in the 2020-2030 period. It was based on the conducted analyses and the latest legislative and organizational actions of the government aimed at facilitating the development of prosumer microgeneration.

Key words: renewable energy sources, prosumer, environmental and energy policy, micro installation, photovoltaic installation, solar collector, heat pump 


\section{Introduction}

The most important objectives of the transformation of Polish energy sector, also achievable through the development of prosumer microgeneration sector, include: the implementation of EU objectives concerning the share of RES energy in total energy consumption, strengthening energy security (especially on a local scale), reducing dependence on the national energy network system, improving technical parameters and reliability of energy supplies, increasing competition and socializing of the energy market, increasing energy efficiency (reducing network losses), improving the environment, using locally available RES resources, developing innovative technological solutions (smart grids), creating local jobs and stimulating the economic development of rural areas. As can be seen, microgeneration plays an important role in the local supply of electricity and heat. The main notion behind the idea of prosumerism is to produce energy and, as technology develops, to store it for later use, primarily for the own needs of the prosumer. The statutory provisions allow for the introduction of produced surplus energy into the distribution network and non-cash payments of the balance of energy taken from and introduced into the network.

Due to the several years of development of the separate sector of micro-installations, including those prosumer type, the author attempted to implement a pilot research programme covering the achieved material effects. The following municipalities of the Siedlce subregion (in total 52), statistical subregion NTS 3, were included in the studied area. For the following counties, the largest database was collected: the city of Siedlce, county of Siedlce, Garwolin, Łosice, Węgrow and Sokołow. To obtain essential and current information on local microgeneration industry, all municipalities of the subregion were asked to fill in questionnaires, which included several detailed questions. They concerned: number and capacity of completed and planned micro-installations for electricity and heat production distributed between public utility buildings and residential buildings, RES technologies utilised, economic support programmes implemented, energy planning documents completed, environmental protection programmes, information and education campaigns carried out for the inhabitants of counties. The problems faced by local governments in the implementation of local energy and environmental policies were inquired about. Another annually updated database of local distribution networks and RES resources connected to these networks was obtained in cooperation with operators of power distribution systems.

The main objectives of the research are:

- comparison of the level of development of the microgeneration sector at the county's level in relation to the Siedlce subregion,

- identification of basic mechanisms and conditions influencing the development of this sector,

- author's assessment of the prospects for the development of microgeneration sector in the light of identified development conditions. These include the latest legislative activities and government aid programmes. 
The schedule of research and analysis works involved several stages, the most important of which are:

- features of the statutory and energy role and tasks of the sector of micro-installations in the energy system of the country. Evaluation of the current development forecasts of the prosumer micro-installations market in Poland with reference to Mazovia Province and the Siedlce subregion,

- $\quad$ assessment of the development level of RES microgeneration for electricity and heat production in particular counties of the subregion. This includes the identification and industry's interpretation of several basic percentage indicators showing the material effects obtained,

- evaluation of investment activity of particular counties in reference to legal conditions, organisational and economic support system, programmes implemented in cooperation with the self-government of Mazovia Province, the income of the counties,

- impact of local infrastructural conditions (condition of distribution networks, energy profiles of municipalities and energy consumers) on the sector development,

- a forecast of the role that the micro-prosumer sector may play in the energetic transformation of the country during 2020-2030 based on identified opportunities and threats,

- $\quad$ summary, including an assessment of the current development level of the microgeneration sector in the Siedlce subregion and development prospects for 2020-2030 in the light of the current environmental and energy policies of the government and the infrastructural conditions.

\section{Prosumer sector - role in the legal and energy system}

The year 2013 should be considered the year when the RES microgeneration sector in Poland legally emerged. This is when it was mentioned for the first time in the domestic legislation on the energy market, in the Act of 26 July 2013 amending the Act of 10 April 1997 - Energy Law and other legal acts. The act provided the legal definition of micro-installations and the system of organizational and economic support dedicated to this sector.

micro installation - a renewable energy source with a total installed electrical capacity not exceeding $40 \mathrm{~kW}$, connected to a power grid with a rated voltage lower than $110 \mathrm{kV}$ or with a total installed thermal capacity not exceeding $120 \mathrm{~kW}$.

The Act of 7 June 2018 amending the Renewable Energy Sources Act and certain other acts (Journal of Laws of 2018, item 1276) extended the sector's energy capacity parameters, so the current definition is as follows:

micro installation - installation of a renewable energy source with a total installed electrical capacity not exceeding $50 \mathrm{~kW}$, connected to a power grid with a rated voltage lower than $110 \mathrm{kV}$ or with a total installed available thermal capacity not exceeding $120 \mathrm{~kW}$, in which the total installed electrical capacity does not exceed $50 \mathrm{~kW}$ 
The Act of 22 June 2016 amending the Renewable Energy Sources Act and certain other acts (Journal of Laws of 2016, item 925) introduced a statutory definition of a prosumer. The subsequent Act of 7 June 2018 amending the Renewable Energy Sources Act and certain other acts (Journal of Laws of 2018, item 1276) provides the following definition:

prosumer - final customer purchasing electricity based on a comprehensive agreement, generating electricity exclusively from renewable energy sources in a micro installation for its own needs only, not related to any business activity regulated by the Act of 6 March 2018 - Commercial Activity Act.

To have the status of prosumer and to use a dedicated network to maintain surpluses of electricity produced in a micro-source, the recipient and at the same time, the producer of energy has to meet several legal and technical requirements. The legislator included the need to produce electricity for own needs using RES micro-installations. It affects a customer who is not an entrepreneur and who has signed a comprehensive contract with an energy company for energy collection and distribution services. A microgenerator that does not meet the above criteria is not a prosumer in the statutory sense. In the technical sense, it could be defined as such, because it was both a consumer and an energy producer. The term prosumer derives from the combination of a syllable: ,pro' from a producer and ,sumer' from a consumer. Therefore, a microgenerator of heat using installation that is not producing electricity cannot be treated as a prosumer.

Common criticism of the practical aspects of the functioning of the prosumer system and the real threat of Poland's not reaching the 2020 target of having 15\% share of RES energy in the total energy consumption, prompted the government to develop and announce in January 2019 a broad Energia Plus programme containing a number of legal and economic solutions. A significant amendment to Renewable Energy Sources Act was developed within its frame, which will include the micro, small and medium enterprises and energy cooperatives in the prosumer system. The Act of 19 July 2019 amending the Renewable Energy Sources Act and certain other acts (Journal of Laws of 2019, item 1524), adopted by the Sejm on 19 July 2019, provides a definition:

renewable energy prosumer - a final customer generating electricity exclusively from renewable energy sources for their own needs using a micro installation, provided that the electricity is consumed by a household and is not related to any business activity pursuant to Article 40, section 2 of the Act of 29 June 1995 on Public Statistics (Journal of Laws of 2019, items 649 and 730).

According to the provisions of the amended act, a prosumer may store the generated energy and sell it not only by meeting certain conditions but also by agreeing to certain terms with any customer.

A producer having the legal status of a prosumer shall benefit from a simplified 30day grid connection procedure. That is, if the electrical capacity of the generating microinstallation is not greater than the capacity of the receiving installation, as specified in the technical specifications. The distribution network operator will cover the costs of installing the protection system of the generating micro-installations and the measurement and settlement system. The Prosumer is to a certain extent exempted from certain installing and distribution fees. A producer of energy that does not meet the requirements of the prosumer 
system has to connect his generating installation to the grid on general terms. This procedure is much longer and more complicated.

The electricity generated by the prosumer installation and entered into the distribution network is balanced with the energy taken from the grid. It is accounted for using coefficients related to the power capacity of the generating installation. Thus, for installations up to and including $10 \mathrm{~kW}$, the ratio is 1 to 0.8 , i.e. for energy introduced into the grid, the generator may receive $80 \%$ of this volume free of charge when acquiring energy from the grid. For installations above $10 \mathrm{~kW}$, the ratio is 1 to 0.7 . An energy-trading company receives free of charge the remaining $20 \%$ or $30 \%$, as a so-called discount [opust]. Hence the system of non-cash operations is commonly referred to as a discount system. The energy producer grants a discount to the energy company, actually giving it a certain volume of energy. The amendment to the Act assumes that for energy cooperatives the ratio for the energy taken from the grid and introduced into it will be 1 to 0.6 .

In the opinion of the author of this study, the term discount is incongruent to the actual state. It is because the above-mentioned volume is not a voluntary donation by a microgenerator to an energy company but a kind of legally enforced participation of the prosumer in the costs of connection and maintenance of the energy distribution and trading system. A very important practical conclusion resulting from the above-mentioned settlement system is the necessity to adjust the electricity capacity of planned micro-installations to the annual demand for electricity to minimize the surplus of energy exported to the grid.

The failures of the government in the development of high-parameter renewable energy sector was a result of its conservative policy towards the coal energy sector and the suspension of wind energy development. These were the reasons for the development and implementation of the above-mentioned Energia Plus programme and My Electricity and AgroEnergy programmes launched in July 2019. They are to be a kind of a lifeline for the domestic RES sector. The programmes are supposed to rapidly accelerate the development of the prosumer microgeneration sector, which is to contribute greatly to Poland's reaching $15 \%$ share of RES in total energy consumption by 2020.

The so-called prosumer package included in the amended acts (the RES Act, Energy Law, Construction Law) contains a number of organisational facilitation, such as: inclusion of the sector of micro, small and medium enterprises and energy cooperatives in the prosumer system, increasing from one to two years the settlement period of the balance of energy produced and consumed by the prosumer, removing the need for construction projects for installations with a capacity of up to $6.5 \mathrm{~kW}$, legalisation of the location of micro-installations in areas with a purpose other than production according to their local spatial management plans, development of executive regulations specifying the rules and procedures for connecting micro-installations to the grid and the scope and rules of energy balancing and its settlement with the prosumers.

In terms of economic support, the Energia Plus programme implemented a thermomodernisation relief in personal income tax, a PKO BP Ekoloan for households and Biznesmax loan guarantees for photovoltaic installations for companies. 
My Electricity programme assumes spending PLN 1 billion on subsidies issued by the National Fund for Environmental Protection and Water Management [NFOŚiGW] to new prosumer photovoltaic installations built by households. The maximum subsidy is PLN 5,000 for a household, which will be paid after the construction of the $2-10 \mathrm{~kW}$ installation is completed. The subsidy is to help in the installation of about 200,000 household microgenerators in the country. The total budget of the AgroEnergy programme aimed at farmers is PLN 200 million, of which PLN 120 million is allocated to returnable forms of financing and PLN 80 million for non-repayable support. Farmers can receive support for projects related to new heat and power sources (including RES) and energy storage facilities.

As of July 2019, the market prices for $1 \mathrm{~kW}$ of power from prosumer photovoltaic installations are around PLN 4,000-5,000, which gives PLN 8,000-10,000 for a $2 \mathrm{~kW}$ installation and PLN 200,000-250,000 for a $50 \mathrm{~kW}$ installation. According to the author's preliminary economic assessment of the cost-effectiveness of household installations with the most common capacities of 3-5 kW, the period of return on investment costs will range from 6 to 8 years. All of the above-mentioned possible economic support options should be utilized though. A much shorter return period takes place when a prosumer participates in EU funds investment programmes implemented by municipalities (e.g. RPO WM). The co-financing rate may reach $80 \%$ in such a case.

According to expert organizations and many potential individual investors, the proposed extension of the prosumers catalogue and new organizational and economic support solutions will not cause an exponential increase in the number of micro-installations in the microgeneration sector. The main driver for its development is the economic profitability of investments on market principles. The installation of photovoltaic installations will start to pay off around 2023 in Poland. This is when the so-called Grid parity (network parity) will be reached, i.e. a situation in which a new source will provide electricity at an average cost no higher than the cost of purchasing energy from the power grid. Reaching this level will give development potential to the entire RES sector, but will stop subsidies and other public support.

\section{Microgeneration sector development prospects}

The [National Plan for the Development of Micro-installations of Renewable Energy Sources until 2030] prepared in 2015 by the Institute of Renewable Energy (IEO) should be considered as comprehensive and pioneering development prospects of the prosumer sector in Poland. The comprehensive analyses of the legal conditions, the government documents, the current system of support for the RES sector and the evaluation of potential resources of green energy all led the team of authors to present a very ambitious concept for the development of the microgeneration sector. It is an important element of the energy, environmental and socio-economic policy of the country. The plan projected specific material effects (capacities of electricity and heat sources, volumes of energy) expected to be achieved in each year. 
The essential financial outlays (public funds) necessary to achieve the set objectives were also determined. The plan contains the technological basis and principles of operation of micro-installations (solar collectors, photovoltaic panels, micro-wind turbines, biomass boilers, heat pumps, micro-cogeneration systems for biogas and bioliquids) and provides the development possibilities for these groups of installations.

The comparison of IEO forecasts with the actual development results of the microgeneration sector for the years 2016-2018 (Table 1) illustrates the very low-performance indicator rate. It reached only $20-26 \%$ of the projected values on the national scale and reached only 6.5-9\% in Mazovia Province. The actual utilisation of technology looks even worse in comparison to the forecasts - the photovoltaic installations are the only ones being developed in the electricity sector. The windmills and cogeneration systems for biogas and bioliquids are scarce. As for the heat microgenerators, only solar installations and heat pumps are developing properly. This group also reached the level of about $20 \%$ of the IEO forecasts.

The 2015 MBPR study [Development of renewable energy sources in Mazovia Province status and challenges], predicted that in 2020 the total capacity of microgenerators in the region would reach $180 \mathrm{MW}$ with a production capacity of $270000 \mathrm{MWh}$. The actual capacity achieved was 37,4 MW with an energy production capacity of approximately $37000 \mathrm{MWh}$ at the end of 2018. Assuming the current dynamics, by the end of 2020 the Mazovian microgneration RES sector may have the capacity at the level of $80 \mathrm{MW}$ with the production capacity of approximately $85000 \mathrm{MWh}$. This will make up for only about $44 \%$ of the capacity and $32 \%$ of the energy of the 2015 forecasts.

As it has been shown, the actual development of the microgeneration sector in Poland and the region (but also of the whole RES sector) is much slower than predicted in the forecasts prepared a few years ago. The reorientation of the government's policy in 2015 to protect the coal industry and the interests of concerns managing the classic corporate energy sector resulted in putting the development of high-parameter renewable energy to a halt and delaying the development of the energy micro-installations sector.

\section{Effects of microgenerators development in Siedlce subregion}

The basic indicator determining the energy effect of connecting a specific volume of electricity from renewable sources to a grid is the share of energy produced by the connected installations in the total energy consumption in an analysed area. It should be recalled that for 2020, this indicator was set at $19.13 \%$ for the whole sector of domestic renewable energy in the (National Renewable Energy Action Plan). There are no forecasts prepared for particular regions or even for the microgeneration sector. As of the end of 2018, there were 749 micro-installations (Fig. 1) with a total installed capacity of $3.836 \mathrm{MW}$ in the low-voltage (LV) distribution network (Fig. 2) of the Siedlce subregion.

These are installations made within the framework of investment programmes of local governments, as well as created by individual investors. Their estimated annual generation 
capacity is about $3.4 \mathrm{GWh}$, which constitutes for $0.52 \%$ of the total electricity consumption in the subregion (data from the distribution network operator for 2018), amounting to 649 GWh. According to the data from [VIII scientific and technical conference, Losses of electricity in power grids 21-22 March 2018, Wroctaw] averaged losses of the low-voltage grids at the national (as well as regional and sub-regional) level amount to (data from 2016) about $4.5 \%$ of the energy transmitted by these grids. In simple terms, it can be stated that at the current stage of development of the micro installation sector, the electricity produced by it in the Siedlce subregion makes up for only about $10 \%$ of the total volume of energy loss in the local low voltage networks.

The summary (Table 2) illustrating the division of micro-installations by power ranges shows that the smallest installations (below $4 \mathrm{~kW}$ ) are predominant, but the installations in the 4-6.9 $\mathrm{kW}$ range are in the lead in terms of total power capacity. The largest installations (21-50 kW) also play an important role in the structure. $2.2 \%$ of the total number of sources generates $16.4 \%$ of the total power of all microgenerating devices connected to the lowvoltage distribution networks in the subregion.

Table 1. Projected vs. actual development of RES microgenerators in the country, Mazovia Province and Siedlce subregion in 2016-2018

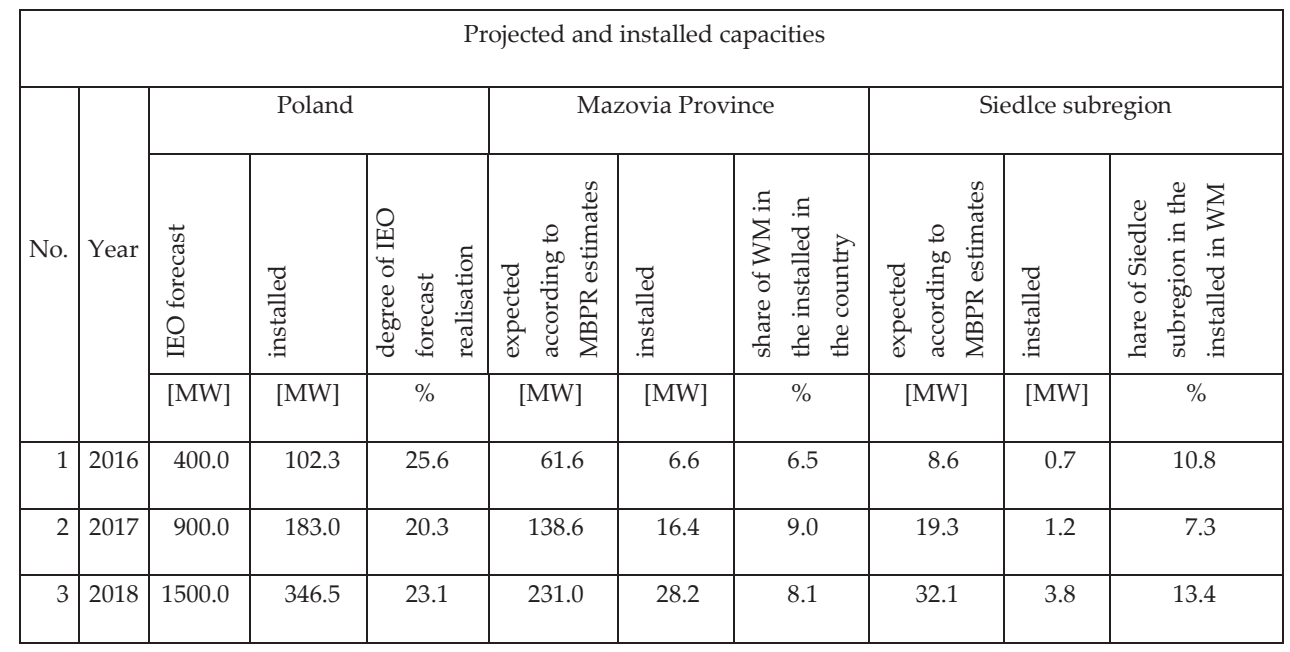

Source: MBPR own elaboration based on IEO projections, BDL data and information provided by municipalities and energy companies 


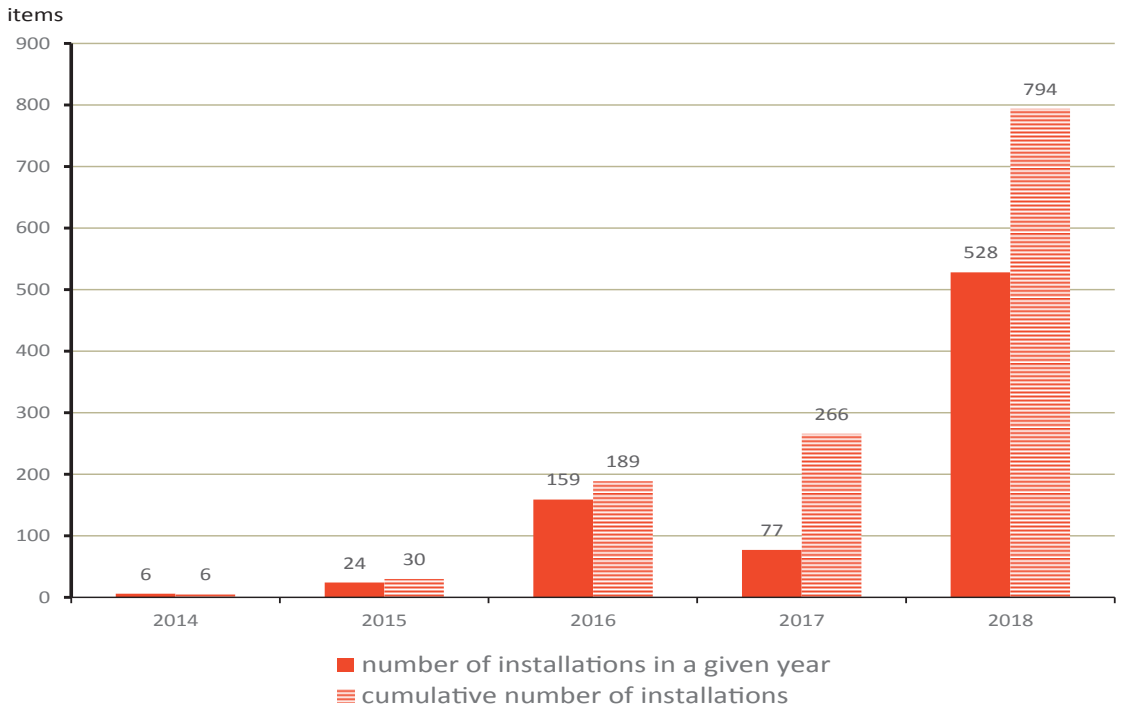

Fig. 1. RES micro-installations connected to low voltage distribution networks $0.4 \mathrm{kV}$ in the Siedlce subregion in 2014-2018

Source: MBPR own elaboration based on data from surveys conducted by the municipalities and from PGE Dystrybucja Inc

power

[MW]

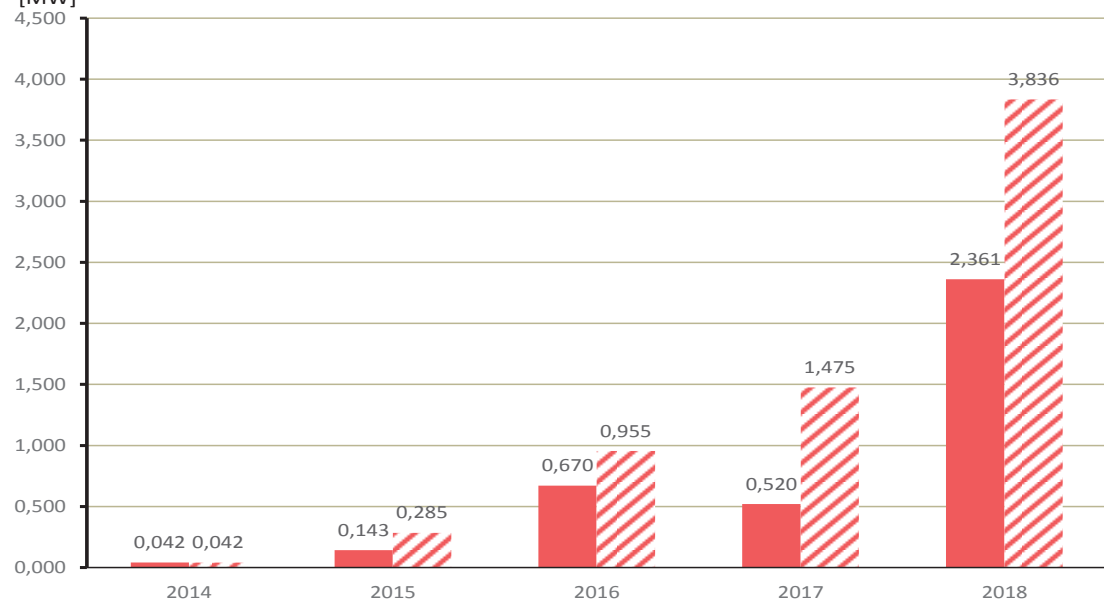

a capacity of the installations connected in a given year $\mathrm{MW}$

4. cumulative capacity of installations

Fig. 2. Power $[M W]$ of the RES micro-installations connected to the low voltage distribution networks $0.4 \mathrm{kV}$ in the Siedlce subregion in 2014-2018

Source: MBPR own elaboration based on data from surveys conducted by the municipalities and from PGE Dystrybucja Inc 
Table 2. RES Microgenerators connected to low-voltage distribution networks $0.4 \mathrm{kV}$ in the Siedlce subregion in 2014-2018 - structure by power ranges of the installation

\begin{tabular}{|c|l|c|c|c|c|c|c|}
\hline No. & \multicolumn{1}{|c|}{$\begin{array}{c}\text { Power } \\
\text { range }[\mathrm{kW}]\end{array}$} & $\begin{array}{c}\text { No. Of } \\
\text { items }\end{array}$ & $\begin{array}{c}\text { \% of the } \\
\text { total }\end{array}$ & $\begin{array}{c}\text { Capacity } \\
{[\mathrm{MW}]}\end{array}$ & $\begin{array}{c}\text { \% of the } \\
\text { total }\end{array}$ & $\begin{array}{c}\text { The average } \\
\text { installation } \\
\text { capacity in } \\
\mathrm{kW}\end{array}$ \\
\hline 1 & Small households & 1 do 3.9 & 388 & 48.9 & 0.979 & 25.5 & 2.52 \\
\hline 2 & $\begin{array}{l}\text { Medium-sized } \\
\text { households, small } \\
\text { agricultural holdings }\end{array}$ & 7 do 6.9 & 292 & 36.8 & 1.242 & 32.4 & 4.25 \\
\hline 3 & $\begin{array}{l}\text { Large households, } \\
\text { medium-sized } \\
\text { agricultural holdings }\end{array}$ & 71 do 10 & 70 & 8.8 & 0.611 & 15.9 & 8.73 \\
\hline 4 & $\begin{array}{l}\text { Public facilities, small } \\
\text { service and production } \\
\text { companies, large farms }\end{array}$ & 26 & 3.3 & 0.377 & 9.8 & 14.50 \\
\hline 5 & $\begin{array}{l}\text { Larger public facilities, } \\
\text { medium-sized service } \\
\text { and manufacturing } \\
\text { companies }\end{array}$ & 21 do 50 & 18 & 2.2 & 0.627 & 16.4 & 34.83 \\
\hline & & & & & & & \\
\hline
\end{tabular}

Source: MBPR own elaboration based on data from surveys conducted by the municipalities and from PGE Dystrybucja Inc

The degree of development of the micro installation sector is highly diversified in spatial terms (Fig. 3). Only in 11 municipalities (21.2\% of units in the subregion), it reached a noticeable value. In these municipalities, the share of electricity produced by micro-installations in the total low-voltage electricity consumption (produced from fossil fuels and RES) is above $1 \%$. In another 8 municipalities $(15.4 \%)$ the indicator is in the range of $0.5-0.9 \%$, i.e. slightly above the average for the subregion. The best results were obtained by municipalities: Stoczek (6.2\%), Korczew (2.6\%), Łochów (2.3\%), Bielany (1.9\%). In terms of installed capacity, respectively: $666 \mathrm{~kW}, 370 \mathrm{~kW}, 97 \mathrm{~kW}, 117 \mathrm{~kW}$.

Another important synthetic indicator, illustrating the level of microgeneration development in a municipality is the so-called system indicator. It determines the ratio of the total power of micro-sources connected to the low-voltage network to the total power of MV/LV transformers installed in a municipality. It is a generalised and technical metric of the municipality connection capacity to the distribution networks. Monitoring of this capacity at the level of individual $\mathrm{MV} / \mathrm{LV}$ transformer stations is common and advised. Such records are supplemented by parameters of the low-voltage line (type and cross-section of wires, the length of circuits, the number of consumers, connection capacities of consumers, peak loads) and are maintained by distribution companies when considering applications for connection of generators.

In the Siedlce subregion (Fig. 4) the discussed indicator was at the average level of $0.8 \%$. The highest values were recorded for the following municipalities: Stoczek 7.4\%, Łochów $3.5 \%$ and Korczew, Bielany and Żelechów - 2.7\% each.

Another, supplementary synthetic indicator illustrating the level of development of the microgeneration sector in municipalities, is the share of electricity consumers using RES microgenerators. The average value for the Siedlce subregion is $0.4 \%$. The following municipalities are the leaders also in this category: Stoczek 5.6\%, Łochów 2.5\%, Bielany 1.7\%, Korczew 1.4\%. 


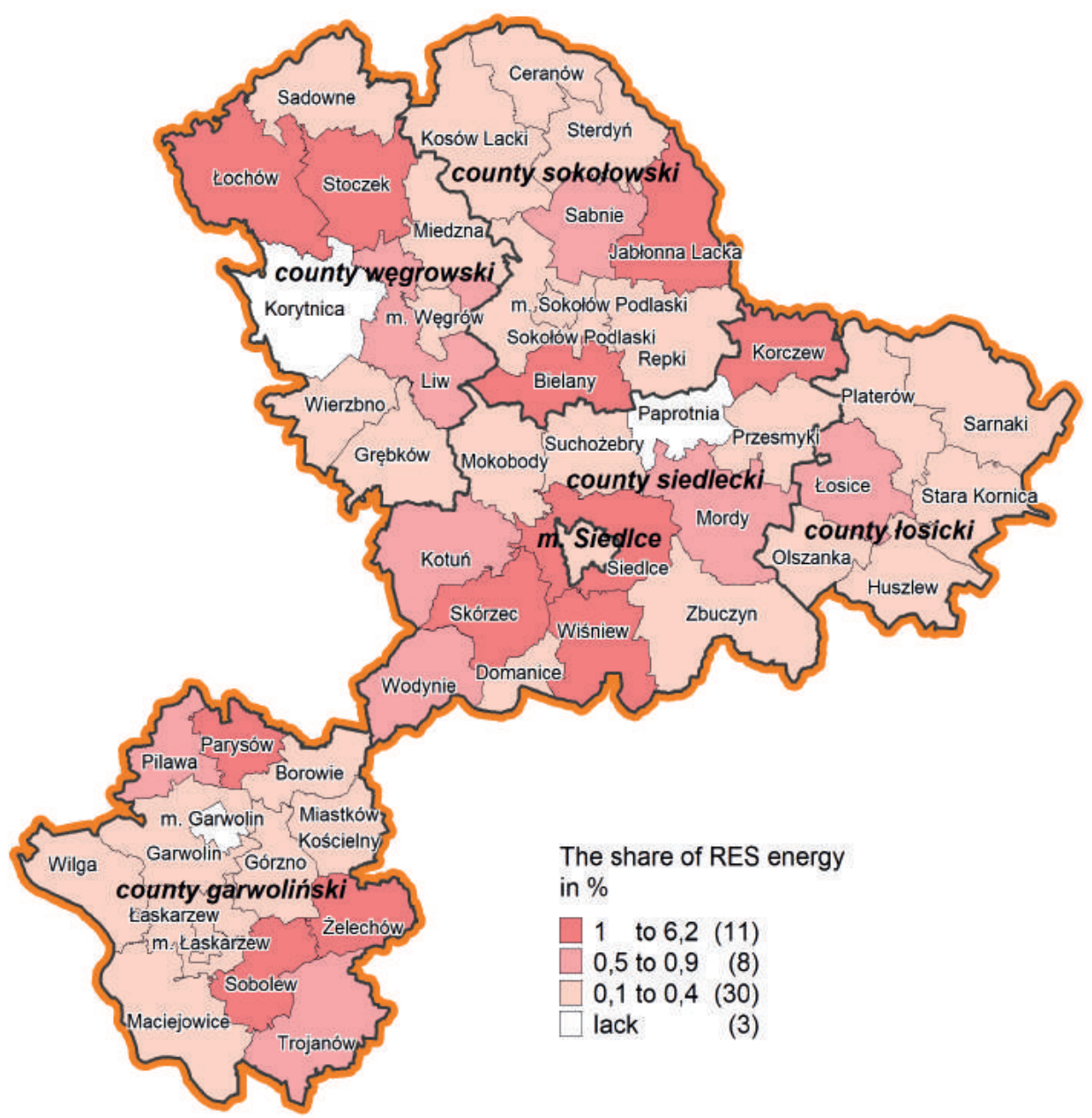

Fig. 3. Share of RES mico-generators in the total low-voltage electricity consumption in the municipalities of the Siedlce subregion - as of 31.12.2018

Source: MBPR own elaboration based on data from surveys conducted by the municipalities and from PGE Dystrybucja Inc

The analysis of the level of development of the microgeneration sector can be summarized by saying that despite nearly six years of functioning of the legal, organizational and economic support system, the material effects achieved are much smaller than expected. Table 1 presents a 2015 author's forecast for the development of prosumer microgeneration sector. The total installation capacity projected for the Siedlce subregion for 2018 amounted to $32.1 \mathrm{MW}$, whereas the actual capacity reached only $3.8 \mathrm{MW}$, i.e. $13.4 \%$ of the forecast volume. For the production capacity, it is about $35000 \mathrm{MWh}$ forecasted and about 3400 MWh achieved. 


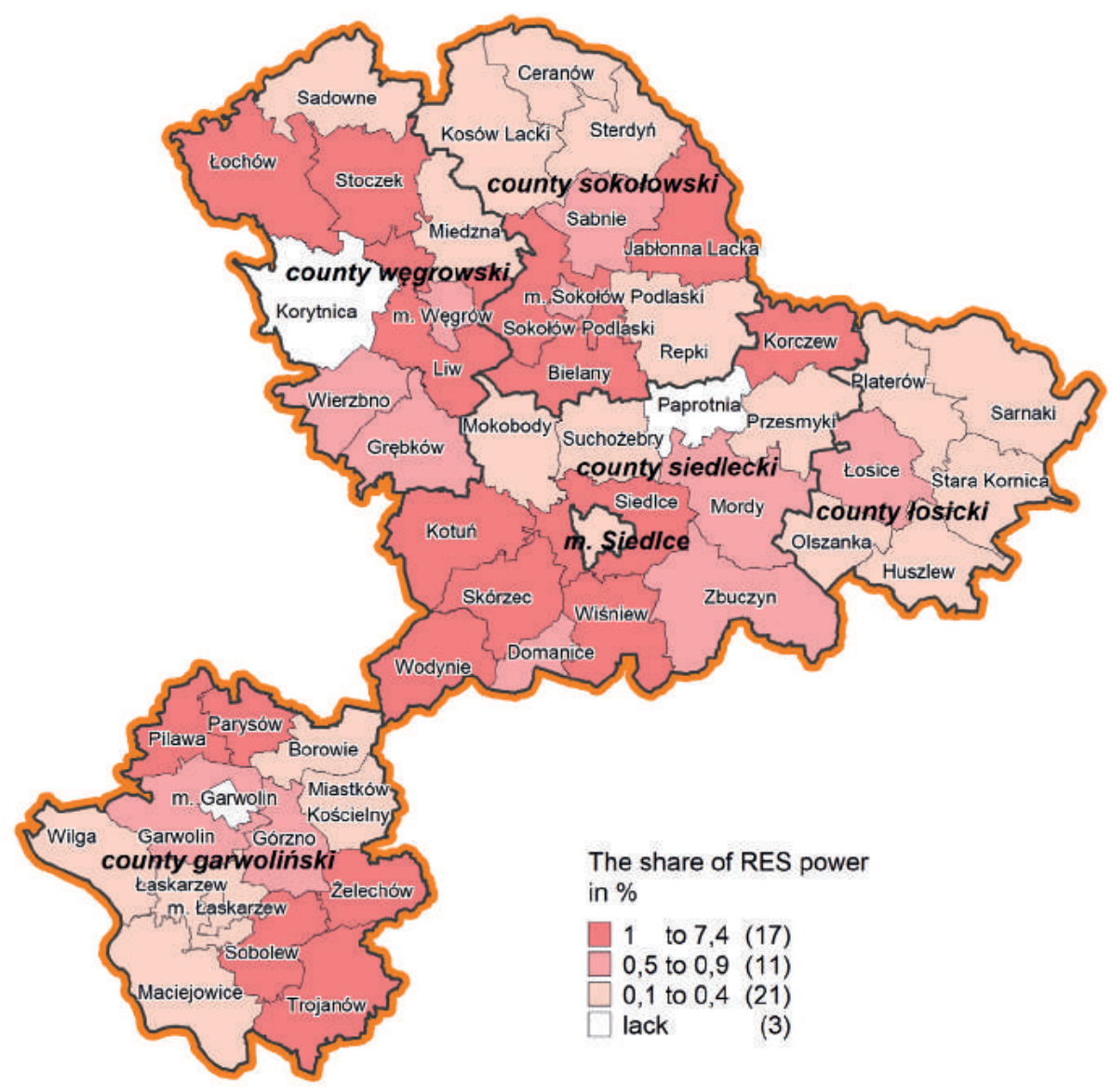

Fig. 4. Share of RES micro-sources capacity in the installed capacity of 15/0.4 kV transformer stations in the municipalities of the Siedlce subregion - as of 31.12.2018

Source: MBPR own elaboration based on data from surveys conducted by the municipalities and from PGE Dystrybucja Inc

The recorded in 2018 annual consumption of low-voltage electricity in the subregion amounted to $649000 \mathrm{MWh}$. The forecasted share of energy generated in the micro-installations connected to the grid was to be about $5.4 \%$, whereas, in reality, it was 10 times lower $(0.52 \%)$. According to the current state of knowledge (July 2019), the forecasts made in 2015 were too optimistic when faced with the actual energy policy of the country and the real support systems which did not meet the social expectations and market rules of energy production and use. Only photovoltaic microgeneration continues to be developed, as out of a total of 794 installations, only one was based on water and wind energy. Within the framework of investments carried out 


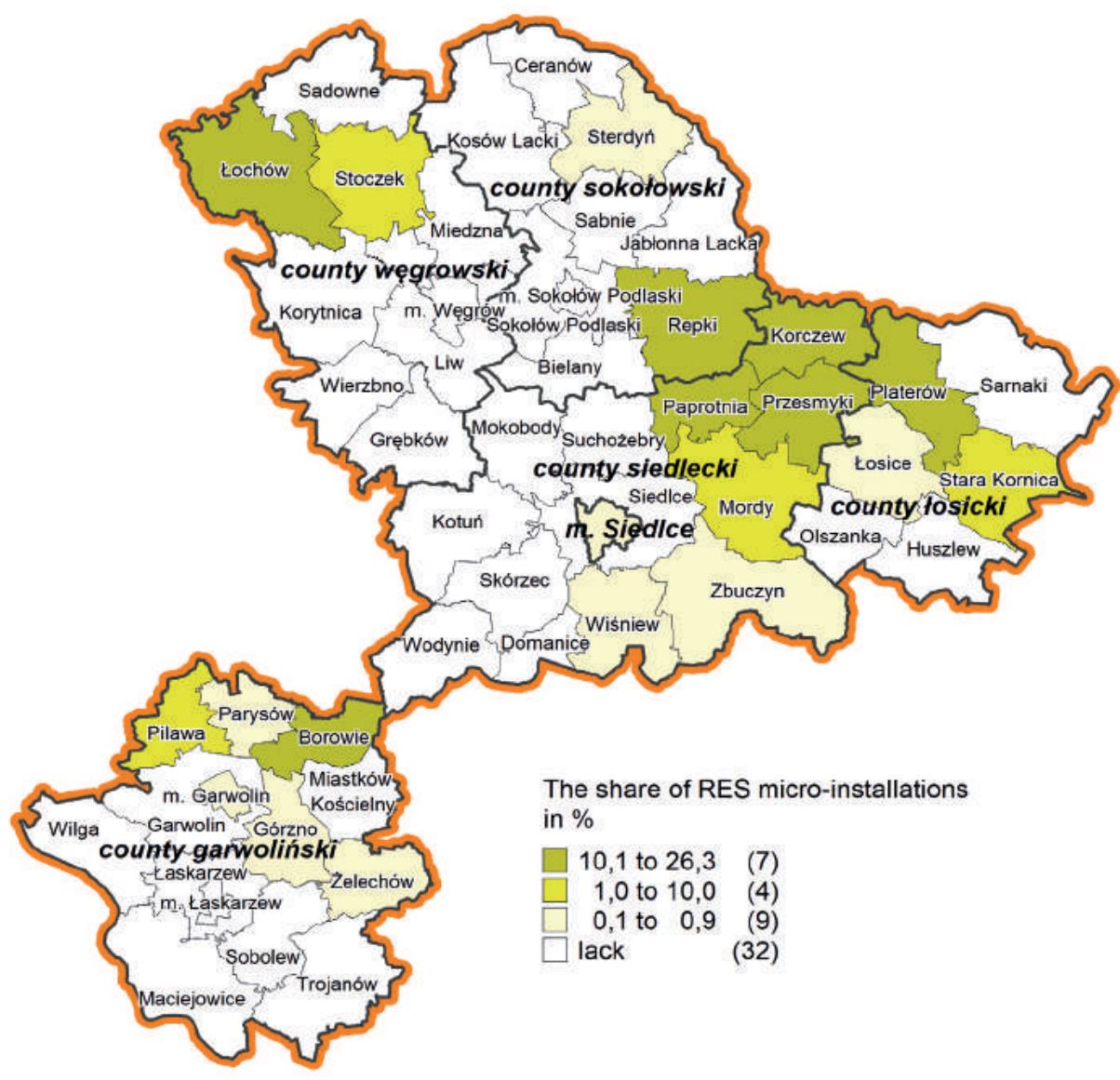

Fig. 5. Share of RES micro-installations in the total number of private heat sources in the municipalities of the Siedlce subregion - as of 31.12.2018

Source: MBPR own elaboration based on data from surveys conducted by the municipalities

by municipal self-governments, 458 microgeneration installations were completed. This number accounts for $57.7 \%$ of all the installations operating in the subregion, and for $43.5 \%$ of the total installation capacity.

Only $20(38.5 \%)$ municipalities of the Siedlce subregion carried out investment activities in the field of heat microgeneration (Fig. 6), but only 7 of them implemented a relatively wide range of investment programmes. These included the installation of solar collectors for domestic hot water heating or heat pumps for space and water heating. The investments were carried out in the municipal public facilities, residential buildings and agricultural holdings. There is no data on micro-heat investments carried out by individual microgenerators outside the municipal self-governments programmes. Such data are not collected by municipal offices 
and construction departments of county Starosties. The only indicator illustrating the level of development of RES heat microgeneration sector is the share of these installations in the total number of all private heat sources. This excludes collective heating systems.

The following municipalities achieved the highest results in developing thermal microgeneration: Repki 26.3\%, Platerów 26.2\%, Przesmyki 25.5\%, Borowie 23.2\%, Paprotnia $22.9 \%$, Korczew $16.5 \%$ and Łochów $14.5 \%$. That is, for 100 individual heat sources, between 26 to 15 use ecological support in preparing hot water or heating rooms. Further 13 municipalities implemented small pilot investment programmes, while as many as 32 of them $(61.5 \%)$ did not.

\section{Investing activity of the Siedlce subregion municipalities}

Within the framework of the study on the implementation rate of investment programmes using EU funds in the particular municipalities of the Siedlce subregion, the below diagrams were prepared. They refer to the number (Fig. 6) and power (Fig. 7) of RES micro-installations divided into installations made and planned per location (public facilities managed by municipalities and municipal residents' buildings) and per technologies used (photovoltaic installations, solar collectors, heat pumps). The graphs show a significant dominance of completed and planned heat production investments for domestic water heating in installations constructed on the basis of solar collectors. The heat pumps used to heat rooms in larger public and production facilities are much less frequent due to the price of such installations. Photovoltaic micro-installations should be considered as very prospective. The highest ratio of planned installations to the number of installations completed (4.5 for the number of installations and 6.6 for the capacity) is recorded in this field. Most of the investments were carried out by municipalities with the use of EU funds under RPOWM [Regional Programme of Mazovia Province] 2007-2013, part of them already in RPOWM 2014-2020. 


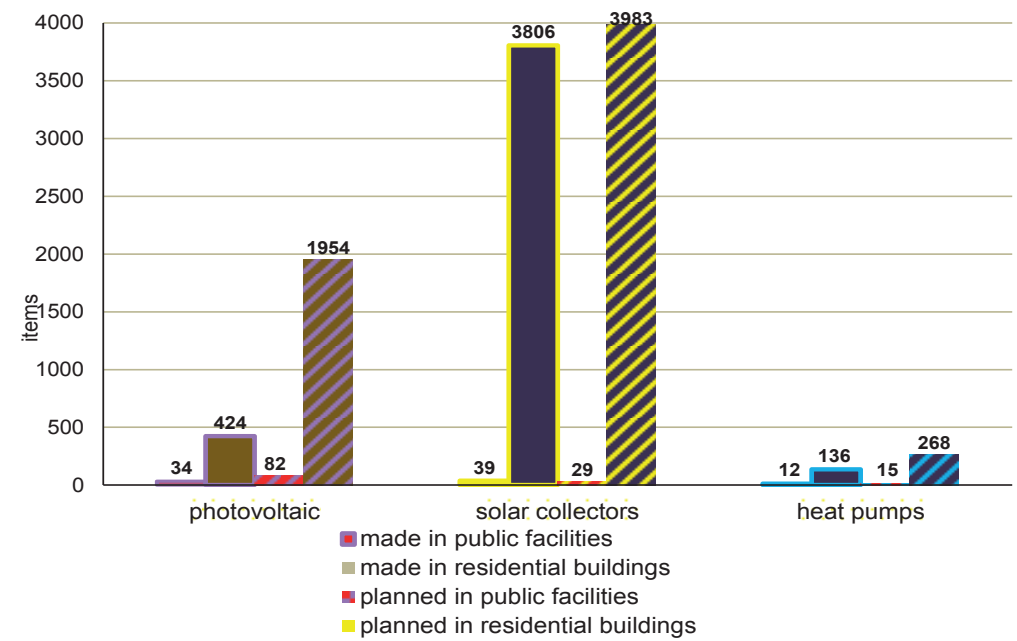

Fig. 6. RES micro-installations completed and planned in the Siedlce subregion within the framework of municipal investment programmes - as of 31.12.2018 Source: MBPR own elaboration based on data from surveys conducted by the municipalities

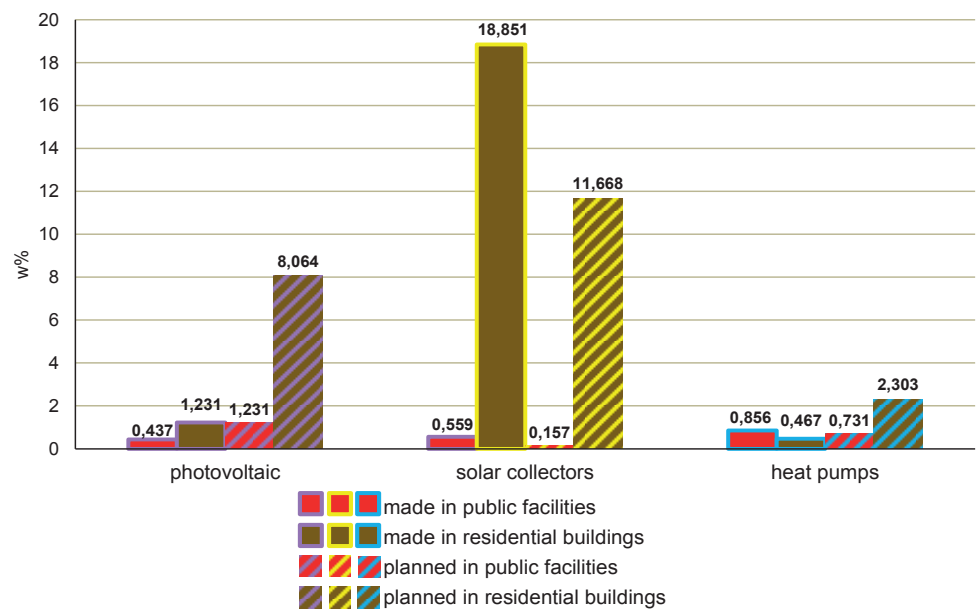

Fig. 7. RES micro-installations capacity in the Siedlce subregion within the framework of municipal investment programmes - as of 31.12.2018

Source: MBPR own elaboration based on data from surveys conducted by the municipalities

Investment programmes aimed at the development of prosumer microgeneration (Fig. 8) were implemented only by 14 (26.9\%) municipalities of the subregion. Only 4 (7.7\%) achieved material effects which can be described as noticeable, i.e. per 100 low-voltage electricity consumers, from 1 to about 10 became prosumers of electricity. Twenty-seven (51.9\%) municipalities declare that they will implement some development programmes. 18 of them $(34.6 \%)$ intend to achieve the target results - from 1 to about 14 photovoltaic installations per 100 electricity consumers. Among the leading municipalities (Stoczek, 
Łochów, Sobolew, Korczew) with the highest number of investments completed, only Korczew plans to implement another photovoltaic installation development programme. Two other municipalities should also be mentioned, i. e. Suchożebry and Platerów, as after having successfully completed their investments they will be leaders in the Siedlce subregion, achieving ratios of 14.4 and 11.5 of prosumer installations per 100 electricity consumers. The fact that as many as 18 municipalities (34.6\%) have not implemented and are not planning (as of July 2019) to implement the prosumer microgeneration development programmes is alarming. This is particularly true of the Garwolin and Łosice counties, where respectively $57.1 \%$ and $50 \%$ of the municipalities have no investment activities or plans.

20 municipalities were active $(38.4 \%)$ in the development of micro-installations for heat production (Fig. 9), of which 11 (21.2\%) implemented investments which resulted in 1 to 26 separate traditional heat sources in municipal facilities or residential buildings receiving support through solar collectors or heat pumps. The most noticeable investment plans are realised by 20 municipalities (38.4\%), a further $5(9.6 \%)$ plan to carry out only minimum works, while $17(32.7 \%)$ are completely passive in developing heat microgeneration. Among those who achieved the best results and continue to pursue an active investment policy are the following municipalities: Repki, Przesmyki, Korczew, Platerów. Stoczek and Paprotnia, which are in the lead, did not take any further actions, while Sokołów Podlaski (rural municipality), Stara Kornica, Olszanka and Suchożebry are the municipalities with the largest scope of planned investments.

Summarizing the analysis of the investment activity of the Siedlce subregion municipalities in the development of heat and electric microgeneration, one should state that despite the 12 years of availability of EU funds supporting the use of RES in improving energy efficiency and the state of the environment and energy security, a significant number of municipalities are completely inactive in this area - 18 municipalities (34.6\%) in electric microgeneration and 17 municipalities (32.7\%) in heat microgeneration.

The survey indicated that this attitude was caused by the lack of financial resources for the municipality's share of investments, a small number of available external resources and lack of interest of the inhabitants. There are also additional subjective reasons, according to the author. However, their identification requires separate, specialised research focused on particular advisory programs addressed to each municipality.

The available data of the Central Statistical Office (GUS) concerning the subregion's municipalities annual income per capita, allowed for a study (Fig. 10) of the impact of the income level (averaged for 2014-2017) on the activity of local governments in the development of heat microgeneration. It is because this sector is dominant in terms of the number and total capacity of installations. The range of values is significant - from the minimum level of PLN 3135 (Wilga) through PLN 3642 (subregion average) to the maximum level of PLN 5482 (Siedlce city). Out of the 4 highest income municipalities, 2 of them implemented investment programmes. Among 19 municipalities with the lowest income, only 6 (31.6\%) were investing actively. However, most of them (except 1 municipality) implemented programmes with low material effects. Of the 29 municipalities with medium income, 11 (37.9\%) were active. 


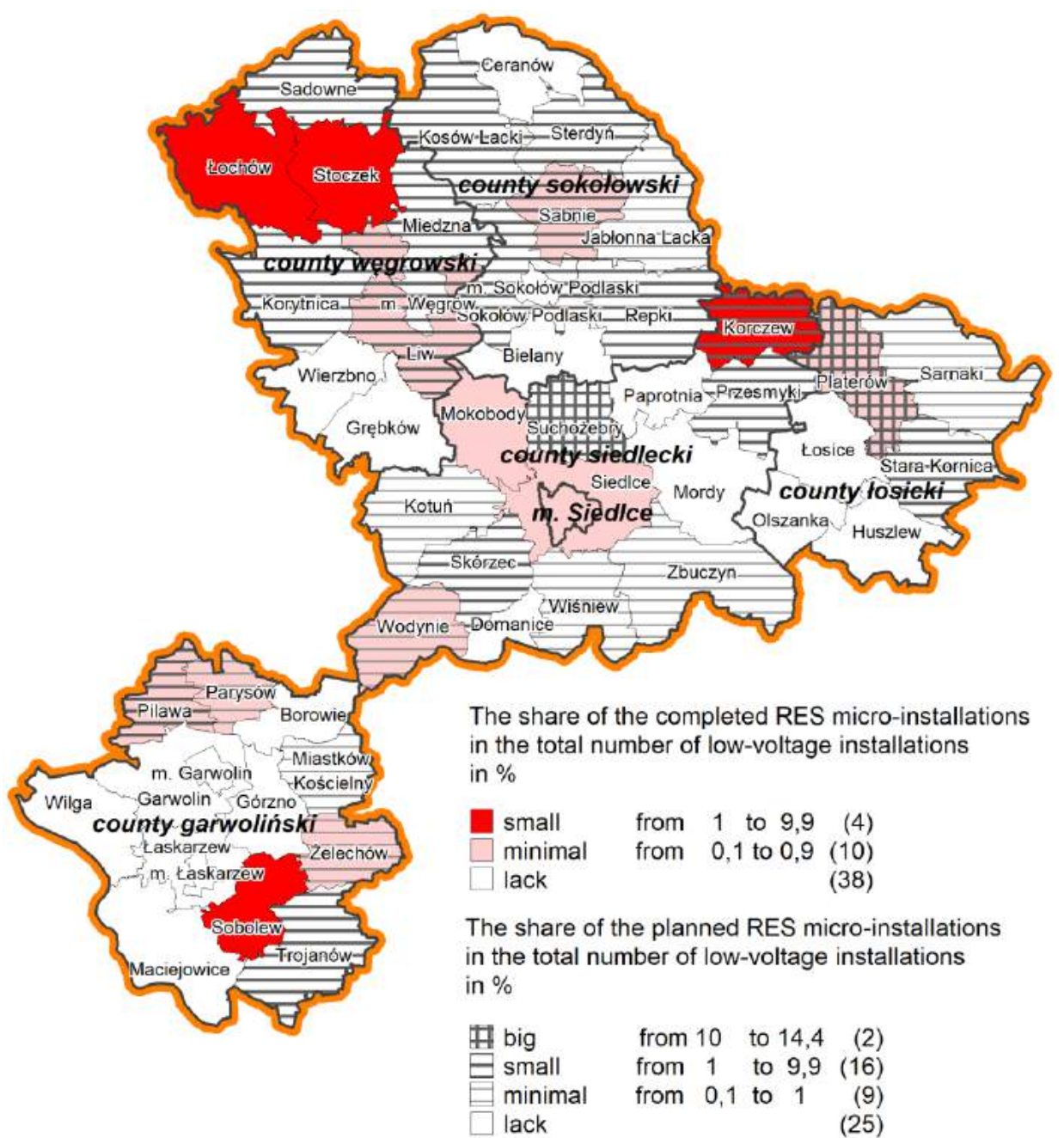

Fig. 8. Investing activity of the Siedlce subregion municipalities in the development of local RES microgeneration - as of 31.12.2018

Source: MBPR own elaboration based on data from surveys conducted by the municipalitie

Among 7 municipalities with the highest investment results 1 belong to high, 5 to medium and 1 to lowest income groups. The income of municipalities has a certain impact on their environmental and energy policy, although this impact cannot be considered as determinant. 


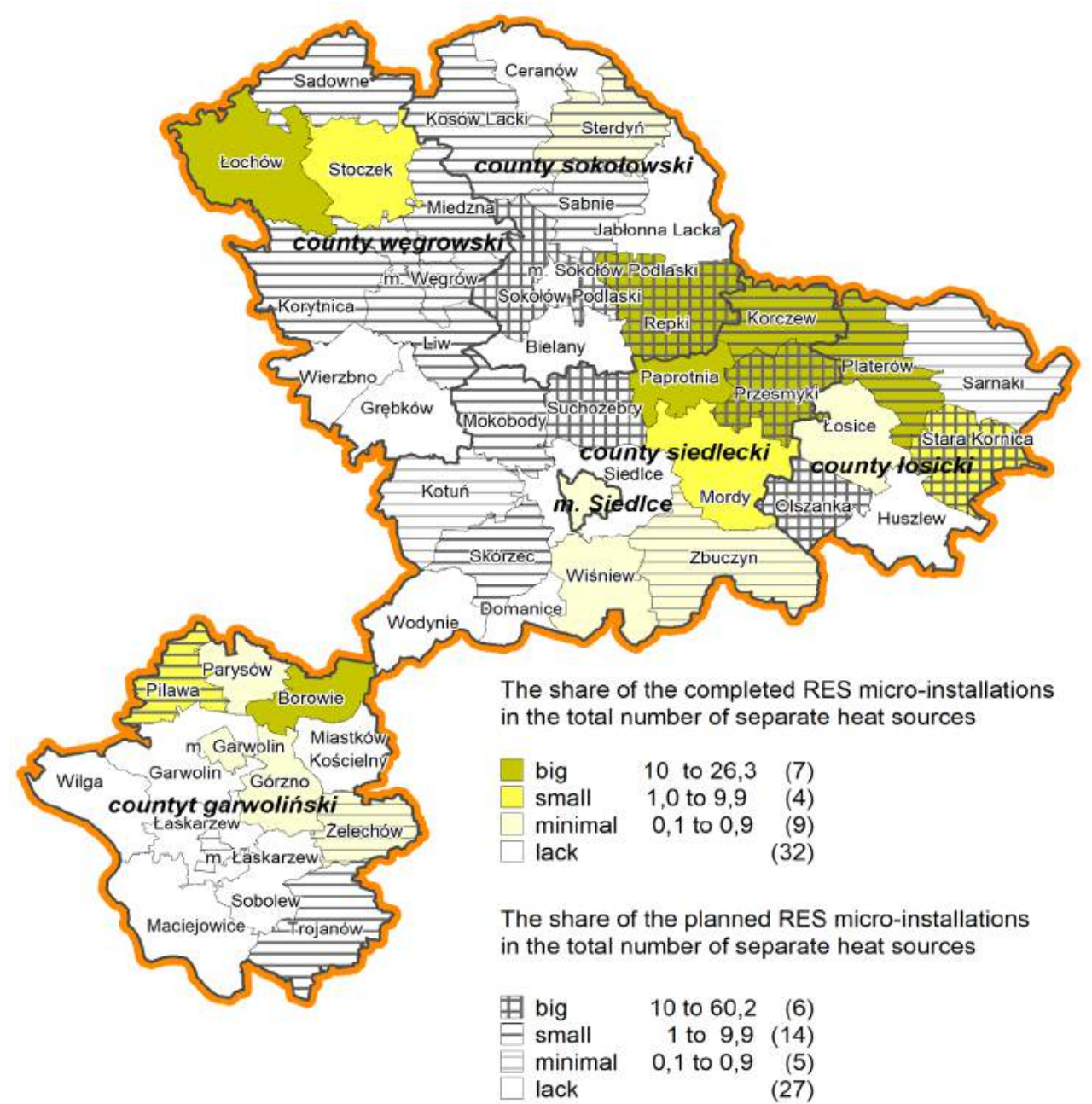

Fig. 9. Investing activity of the Siedlce subregion municipalities in the development of renewable thermal microgeneration - as of 31.12.2018

Source: MBPR own elaboration based on data from surveys conducted by the municipalities

Among other (other than financial) factors that were diagnosed in the survey of the Siedlce subregion municipalities, the following were considered as very significant:

- planning activity of municipalities in the energy and environmental sectors, based on the preparation of basic documents, i.e: estimates for the heat, electricity and gas fuels supply plans as well as for the low emission economy plan,

- educational activities in the field of environmental and energy policy,

- the extent of the interest of the residents in the development of modern local RES microgeneration. 


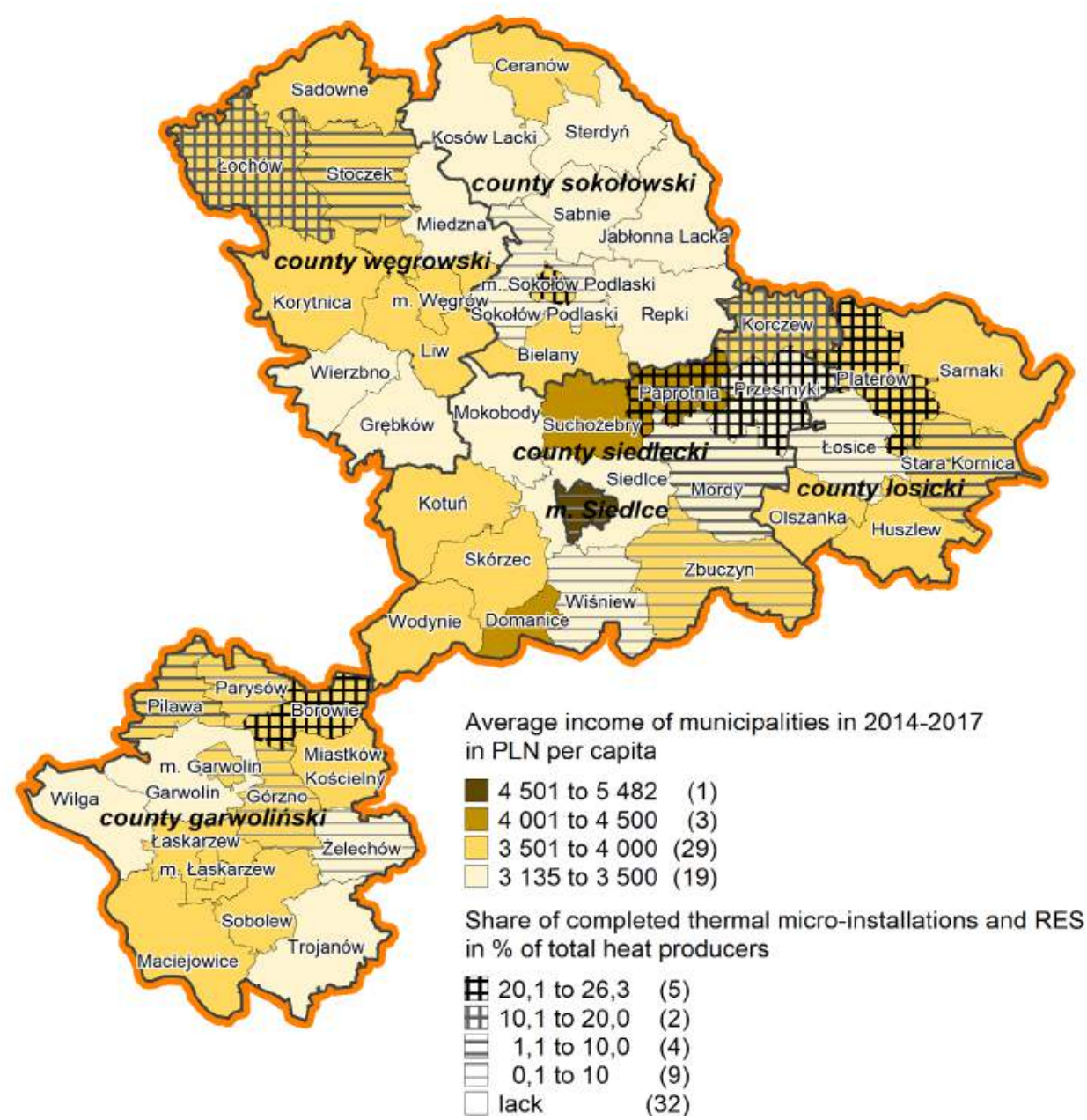

Fig. 10. Impact of the income of the Siedlce subregion municipalities on their investing activity in the area of a thermal microgeneration - RES micro-installations as of 31.12.2018

Source: MBPR own elaboration based on data from surveys conducted by the municipalities and data of the Central Statistical Office (GUS)

Out of 19 municipalities with the highest planning activity (2 prepared planning documents), 12 (63.2\%) municipalities implemented local microgeneration investments (total for electricity and heat production). Among 25 municipalities with 1 planning document available, 12 (48\%) were involved. Investment programmes were also implemented by 3 out of 8 municipalities (37.5\%) which did not prepare planning documents. Of 14 municipalities, which indicated a high interest of residents in the development of local microgeneration sector, $8(57.1 \%)$ made some investments. In the group of 32 municipalities with average interest, $13(40.6 \%)$ carried out certain actions. Out of 15 municipalities which organised information programmes for their residents, 7 (46.7\%) also managed to achieve measurable 


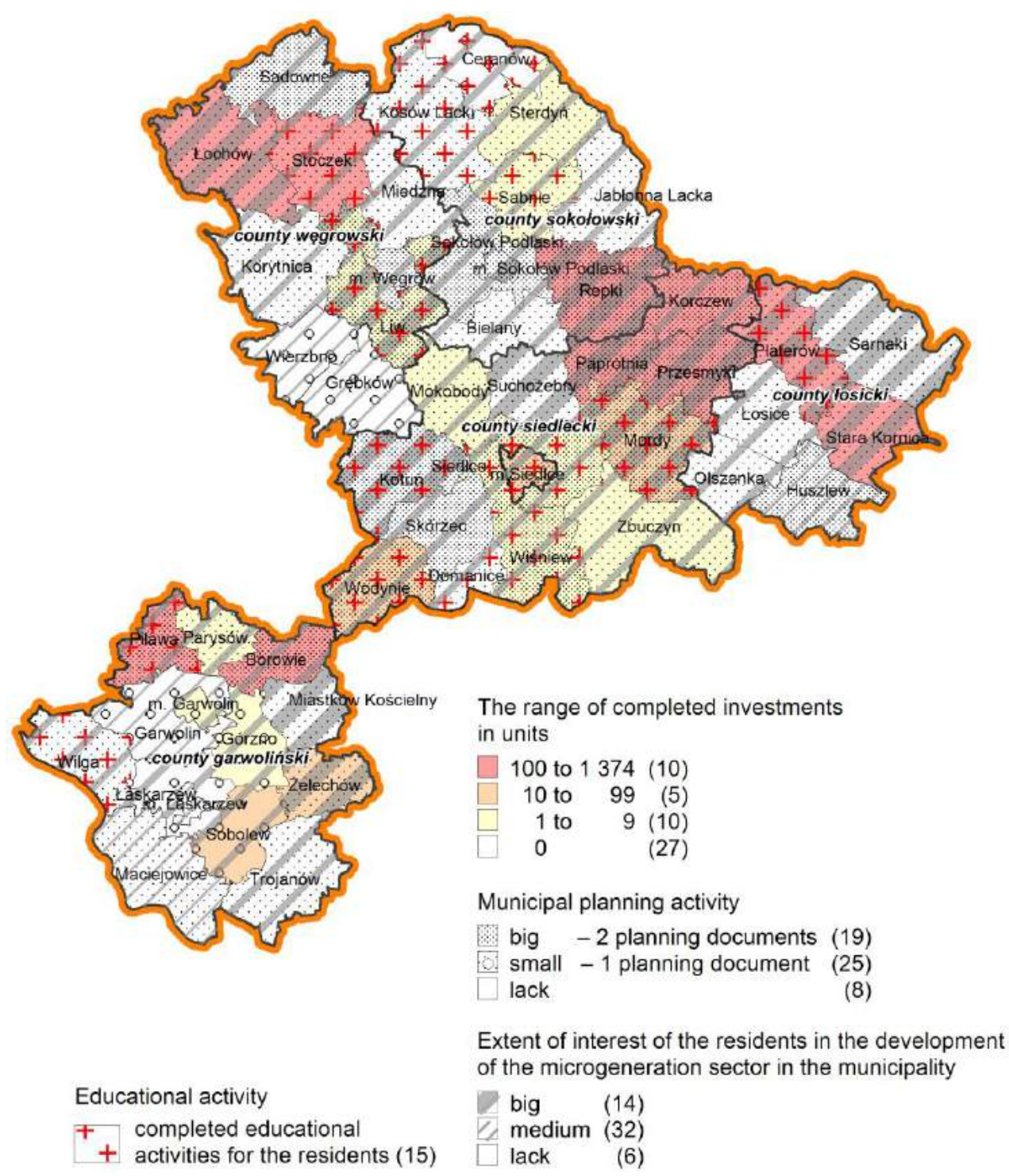

Fig. 11. The influence of planning and educational activity of the Siedlce subregion municipal authorities and the extent of the interest of the residents in the development of the prosumer energy Source: MBPR own elaboration based on data from surveys conducted by the municipalities

investing effects. In conclusion, a relatively high rate of planning activity of municipalities, amounting to $84.6 \%$, as well as a similar share $(85.2 \%)$ of the units with a high and medium level of interest of residents in the local energy sector did not translate into the investment results achieved. Only $48.2 \%$ of municipalities as of July 2019 managed to achieve such results. $30.8 \%$ of local governments are in the process of implementing or planning certain 
investments. Therefore, $79 \%$ of the Siedlce subregion municipalities are involved in the process. Due to the lack of available information, it is not yet possible to compare the analysed subregion with other subregions of Mazovia Province and the country.

\section{Local infrastructural conditions}

Among the many determinants of the development of the microgeneration sector, the least diagnosed and, consequently, not yet available in the published sources are local infrastructural conditions. They are the basic technical and operational parameters of the local MV/LV distribution networks. This is because the development process of prosumer microgeneration is at an early stage, therefore there is still no practical experience in planning and connecting a large number of unstable generation installations to the grid. Generators accumulated in local network nodes, such as MV/LV transformer stations, may significantly interfere with the operation of these nodes. This is especially true when the voltage levels required by law are destroyed. Connection to the existing LV network may also be very problematic, even for a single micro-installation with a capacity ranging from $10 \mathrm{~kW}$ to 50 $\mathrm{kW}$. To minimize the problem, there is a need for cooperation and exchange of information between the distribution network operator and a municipality, which wishes to build a significant number of prosumer microgeneration sources in its area. A list of residents willing to have their own energy should be verified against the planned number and capacity of sources to be connected to particular transformer units. The list should be compiled by the municipality so that the distribution company can carry out the necessary adaptation works beforehand. The obligation, imposed by law and recently extended (July 2019) to include a group of small and medium-sized companies, to connect prosumer micro-sources to the grid cannot be a reason for the deterioration of the quality of energy supplied. This affects those consumers who are located in the area where the installations are connected.

Table 3. Electricity profile of the Siedlce subregion municipalities by types of municipalities

\begin{tabular}{|l|c|c|c|c|c|}
\hline $\begin{array}{l}\text { Type of } \\
\text { municipality }\end{array}$ & $\begin{array}{l}\text { Average power per } \\
\text { transformer station } \\
15 / 0.4[\mathrm{kVA}]\end{array}$ & $\begin{array}{l}\text { Number of customers } \\
\text { per transformer station }\end{array}$ & $\begin{array}{l}\text { Power per } \\
\text { customer [kVA] }\end{array}$ & $\begin{array}{l}\text { Annual energy } \\
\text { consumption per } \\
\text { customer [kWh] }\end{array}$ & $\begin{array}{l}\text { Min and maximum energy } \\
\text { consumption [kWh] }\end{array}$ \\
\hline Urban & 274 & 109 & 2.5 & 3339 & $\begin{array}{c}3020 \text { Siedlce } \\
5118 \text { Łaskarzew }\end{array}$ \\
\hline Urban-rural & 120 & 36 & 3.5 & 3160 & $\begin{array}{c}2893 \text { Łochów } \\
3882 \text { Łosice }\end{array}$ \\
\hline Rural & 83 & 28 & 2.9 & 3862 & $\begin{array}{c}2244 \text { Stoczek } \\
5536 \text { Olszanka }\end{array}$ \\
\hline Subregion & 112 & 40 & 2.8 & 3581 & $\begin{array}{c}2244 \text { Stoczek } \\
5536 \text { Olszanka }\end{array}$ \\
\hline
\end{tabular}

Source: MBPR own elaboration based on data from PGE Dystrybucja Inc 
Table 4. Network profile of MV/LV in Minsk and Siedlce municipalities by year of construction

\begin{tabular}{|l|c|c|c|c|}
\hline $\begin{array}{l}\text { Network } \\
\text { construction } \\
\text { years - decades }\end{array}$ & $\begin{array}{l}\text { MV/LV network units } \\
\text { in the municipalities of } \\
\text { Minsk County [units] }\end{array}$ & $\begin{array}{l}\text { MV/LV network units } \\
\text { in the municipalities of } \\
\text { Siedlce County [units] }\end{array}$ & Together [units] & Share of the decade in \% \\
\hline Before 1970 & 338 & 154 & 492 & 16.4 \\
\hline $1970-1979$ & 324 & 291 & 615 & 20.5 \\
\hline $1980-1989$ & 324 & 352 & 676 & 22.6 \\
\hline $1990-1999$ & 196 & 178 & 374 & 12.5 \\
\hline $2000-2009$ & 99 & 172 & 271 & 9.0 \\
\hline $2010-2019$ & 351 & 218 & 569 & 19.0 \\
\hline Total & 1632 & 1365 & $\mathbf{2 9 9 7}$ & $\mathbf{1 0 0 . 0 0}$ \\
\hline
\end{tabular}

Source: MBPR own elaboration based on data from PGE Dystrybucja Inc

The paper presents (Table 3) a basic, general energy profile of the Siedlce subregion municipalities and a statistical (Table 4) network units' profile of MV/LV transformer with connected low-voltage lines. The technical indicators will be used for a pioneering attempt,

simplified and very general, to estimate the total connection capacity of distribution networks operating in a given area.

Technological condition, networks, their type and work layout are of fundamental importance when assessing connection capacity. This is why a basic, generalised diagnosis of local MV/LV distribution networks is necessary. It is based on own research conducted in 2000-2019 for Siedlce and Minsk counties (located outside the Siedlce subregion but also representative for eastern Mazovia). This research was carried out to provide a statistical profile of age structure and characteristics of local distribution networks. This profile was based on approximately 3000 network units and is representative for the MV/LV distribution networks of the whole Siedlce subregion. It can, therefore, be used for this article. Such a conclusion was formulated based on experience and practical knowledge gained by the author during more than 30 years of work on planning and designing of extensive network systems.

The major problem of the vast majority of networks, especially the rural MV/LV distribution networks, is the fact that they were designed as overhead devices suitable only for energy reception. Very often, the power values for particular groups of customers and the simultaneity coefficients, as it has turned out, are too low. With long circuits of LV lines, low cross-sections of wires and too high loads, the parameters of energy supplied to consumers deteriorate significantly.

The oldest networks, built before 1980, are in a relatively poor technical condition and have not been fully modernised so far. The share of such units in the Siedlce subregion is about $36.9 \%$, which accounts for about 1600 units out of the total of 4500 in the subregion. According to our analyses, the statistical station's average connection capacity of microsources of energy, not causing significant disturbances to its operation, is approximately $15 \%$ of the number of its connected consumers. The statistical power output of a single source is $4.8 \mathrm{~kW}$ (Table 5). It may, therefore, turn out that in the case of larger capacities (especially 
Table 5. Average capacity of RES micro-installations installed and planned in the Siedlce subregion - as of 31.12.2018

\begin{tabular}{|c|c|c|c|c|c|}
\hline $\begin{array}{c}\text { Type of micro } \\
\text { installation }\end{array}$ & $\begin{array}{c}\text { Made in } \\
\text { public } \\
\text { facilities }[\mathrm{kW}]\end{array}$ & $\begin{array}{c}\text { Made in } \\
\text { residential } \\
\text { buildings } \\
{[\mathrm{kW}]}\end{array}$ & $\begin{array}{c}\text { Planned in public } \\
\text { facilities [kW] }\end{array}$ & $\begin{array}{c}\text { Planned in } \\
\text { residential } \\
\text { buildings [kW] }\end{array}$ & $\begin{array}{c}\text { All municipal } \\
\text { and individual } \\
\text { PVs completed } \\
\text { together [kW] }\end{array}$ \\
\hline Photovoltaic & 12.9 & 2.9 & 15.0 & 4.1 & 4.8 \\
\hline
\end{tabular}

Source: MBPR own elaboration based on data from surveys conducted by the municipalities and from PGE Dystrybucja Inc

above $10 \mathrm{~kW}$ ), the technical parameters of some units may not guarantee a single secure connection without the necessary modifications or upgrades.

The second group of network units $(35.1 \%$ of 4500 , or about 1580$)$ are devices built between 1980 and 2000. Their circuit lengths, cable cross-sections and preset capacity parameters allow for the connection of about $25 \%$ (of all the connected consumers) of microsources of energy. Indisputably, that sources above $10 \mathrm{~kW}$ require specific case studies.

The most modern units, built or completely modernised after 2000, are in the relatively best position. These are often cable and overhead power lines with quite stable energy parameters, which enables the connection of microgenerators amounting to up to $35-40 \%$ of all customers. There are $28 \%$ of such units in the subregion, i.e. about 1260 units. Microgenerators with a power of up to $50 \mathrm{~kW}$ can already be connected to some circuits of the LV network. The analyses do not distinguish city stations operating in ring cable systems separately, because the specificity of urban areas and the characteristics of buildings create a different set of development conditions for the microgeneration sector.

The obtained data and their analyses were used to calculate the estimated total capacity of a micro-installation which can be connected to distribution networks in the Siedlce subregion in their current technical condition. It is, however, only a hypothetical and indicative value, requiring further verification operations. The activities should be performed on detailed and updated databases and based on the practical experience of distribution plants in connecting microgenerator units to specific types and network systems.

For the assumed power capacity of a single microgenerator installation amounting to $4.8 \mathrm{~kW}$, the total estimated connection capacity is around 43,000 sources, which is approximately:

- $24 \%$ of the 180,000 customers located in the subregion,

- $44 \%$ of the total active power of $467 \mathrm{MW}$ installed in MV/LV transformers,

- $28 \%$ of the total subregion consumption of low-voltage electricity amounting to 649 $\mathrm{kWh}$ at the end of 2018.

Taking into account the above factors, as well as the expected impact of the significant, favourable changes in the legal, organizational and economic conditions for the microgeneration sector to be introduced in the country, the Siedlce subregion may reach the share of about $2.2 \%-3 \%$ of the micro-sources of electricity in the total energy consumption 
by the end of 2020. Provided that the municipal investment plans are fulfilled. The results achieved by the leading municipalities in 2018: Stoczek (6.2\%), Korczew (2.6\%), Łochów $(2.3 \%)$, Bielany $(1.9 \%)$ confirm the feasibility of the forecast related to the entire subregion.

As mentioned earlier, the process of development of prosumer microgeneration should be supervised. This applies in particular to large municipal programmes, which will result in significant amounts of microgenerators or sources of higher capacity being connected to the grid. The investor's cooperation with the distribution company will enable the harmonious use of the existing network infrastructure and proper planning of its modernisation and expansion. This will allow achieving appropriate energy and environmental effects while minimizing expenditures. The specific problems and characteristics of the network systems supplying particular municipalities are illustrated graphically (Fig. 12). The issues requiring cooperation and mutual support of the parties involved in the RES microgeneration development process are highlighted. The choice of the power capacity of the planned generator, adequate to the needs and energy profile of the customer and the organization of energy consumption, that is supposed to maximize the own utilisation of the produced energy, is extremely important. Until the construction of economically viable energy storage facilities limiting the transmission of surplus energy generated by prosumer microinstallations to the grid, the development of this sector of renewable energy will be hindered. This is due to a large number of dispersed micro-sources of energy, which is especially relevant for rural distribution networks.

\section{Summary of research results}

Summarizing the analysis of the level of development of the microgeneration sector, it should be noted that despite nearly six years of legal, organizational and economic functioning of the dedicated support system, the material effects achieved are much smaller than expected. The forecasts prepared in 2015 by the Institute of Renewable Energy turned out to be significantly overestimated. Comparison of IEO forecasts of microgenerators power volumes with the actual results achieved in 2016-2018 illustrates the very low rate of forecast realization. It reached the value of only about $20-26 \%$ on the national scale for the analysed years. For Mazovia Province, it was even less, i.e. only 6.5-9\%. The author of this article's 2015 forecasts for electricity generated in micro-installations connected to the grid in the overall energy consumption turned out to be incorrect as well. According to these projections, their share in the Siedlce subregion was to reach approx. 5.4\% at the end of 2018. It was almost 10 times smaller $(0.52 \%)$ in reality. The investments carried out by municipal self-governments in the analysed subregion accounted for $57.7 \%$ of all completed micro-installations and $43.5 \%$ of the total installation capacity. Only $26.9 \%$ of the subregion's municipalities implemented investment programmes, of which only $7.7 \%$ achieved noticeable material effects, i.e. per 100 low-voltage electricity consumers, from 1 to about 10 consumers became prosumers of electricity. The implementation of development programmes is declared by $51.9 \%$ of 


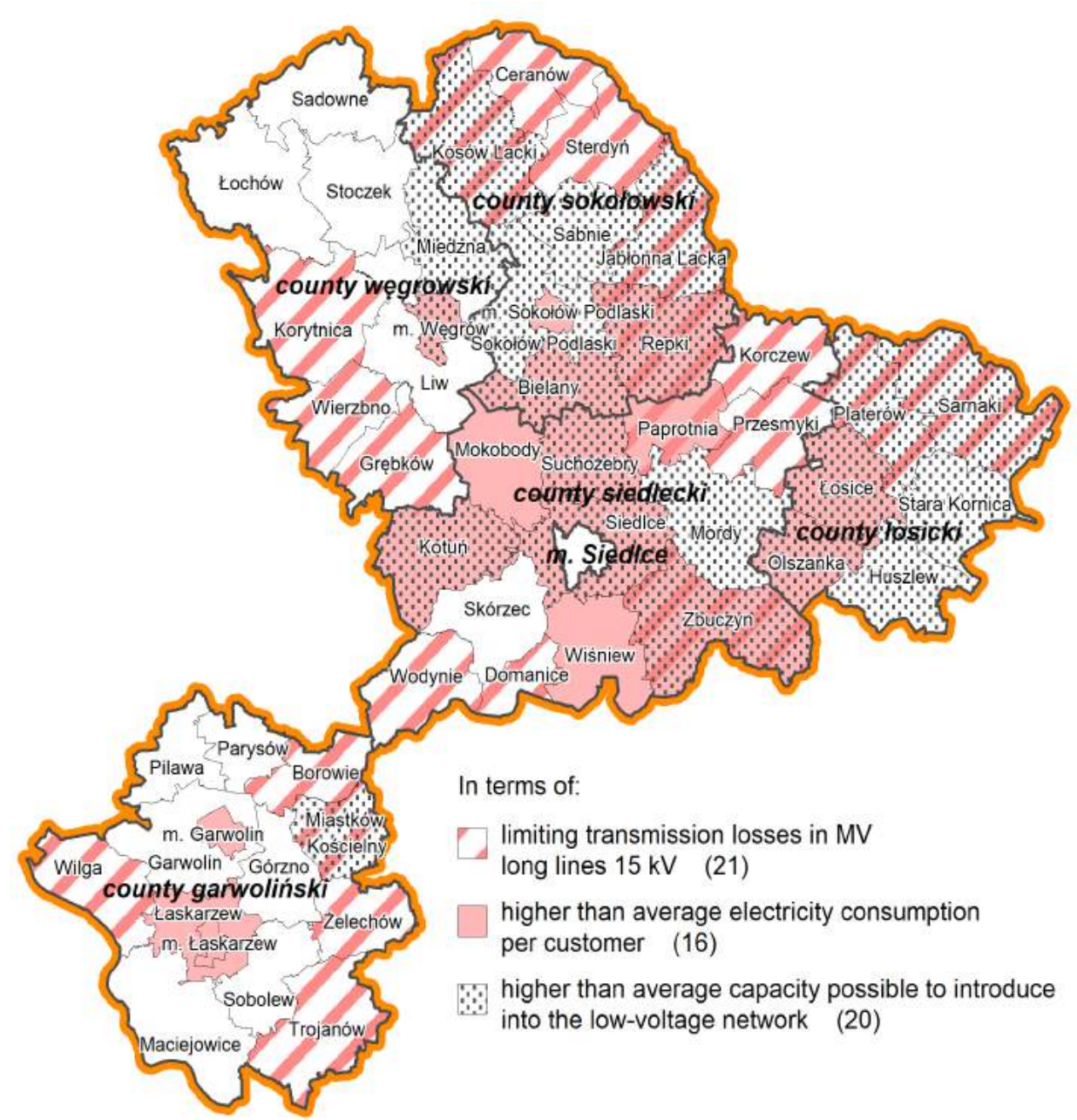

Fig. 12. Municipalities of the Siedlce subregion preferred for special coordination and support in the development of local prosumer micro-installations

Source: MBPR own elaboration based on data from PGE Dystrybucja Inc

municipalities, of which $34.6 \%$ intend to achieve the target of 1 to about 14 photovoltaic installations per 100 electricity consumers. As many as $34.6 \%$ did not implement and do not plan any programmes for the development of prosumer microgeneration.

As far as the microgeneration of heat is concerned, only $38.5 \%$ of municipalities in the Siedlce subregion carried out certain investment activities. However, only $13.5 \%$ of them have a relatively broad scope, i.e. out of 100 individual heat sources, from about 15 to 26 use ecological support to prepare hot water or heat rooms. $25 \%$ of the municipalities implemented small pilot investment projects, whereas $61.5 \%$ did not do any. $38.5 \%$ of them have investment plans of significant scope, while $32.7 \%$ have not completed and do not plan to complete any investments in the micro-heat sector. The effectiveness of forecasts for micro- 
heat installations is not reliable at present due to the lack of data on the capacity and number of installations made by private investors outside municipal programmes.

\section{Conclusions}

1. The reasons for the lack of activity or a small scope of investments in the microgeneration sector are the lack of own funds and a small number of external resources, including those allocated for RPOWM 2014-2020. According to the author of the article, subjective factors are also at stake. They include the lack of qualified personnel capable of effectively conducting large and specialised investment programmes, lack of broad public support for spending public funds for this purpose and financial participation of residents in investments.

2. The economic realities until 2018 were not conducive to development. Many specialised analyses demonstrated the unprofitability of investments in energy microinstallations in the present legal status, the price of generators and energy storage devices, and the energy efficiency achieved. The return on investment is still too long.

3. Significant legislative changes introduced in 2019 include micro, small and medium-sized companies and energy cooperatives in the prosumer sector. Together with government support and organisational and economic programmes, they may significantly accelerate the development of prosumer microgeneration. However, according to the author, a real breakthrough will take place when unit prices of the prosumer generated energy drop below the purchase prices of energy from distribution networks.

4. The current state of knowledge on the level of development of prosumer microgeneration in the Siedlce subregion and on local and national conditions for this development could indicate that at the end of 2020 the subregion may reach the share of energy produced in this sector in the total consumption at the level of approx. $2.2 \%-3 \%$. The prospects for 2030 will be possible to estimate only around 2023-2024.

5. Economic and effective use of the capacity of local distribution networks to connect microgenerators is required. Therefore, it is necessary to establish close cooperation between investors (especially municipalities) and the operators of the energy system.

6. Experience gained during the analysis of the state of development of prosumer microgeneration in the Siedlce subregion is of significant importance. This research should be extended to the entire Mazovia Province, and comparative analysis should be carried out with national results. 


\section{References}

Cieszkowski Z., 2018, Renewable sources of electricity in the Mazovia region, MAZOWSZE Studia Regionalne, 26, Mazowieckie Biuro Planowania Regionalnego, Warszawa, pp. 61-87.

Cieszkowski Z., Girczuk J., Polak E., 2015, Rozwój energetyki opartej na źródłach odnawialnych $w$ województwie mazowieckim - stan i wyzwania, MAZOWSZE Analizy i Studia, 3, 44, Mazowieckie Biuro Planowania Regionalnego, Warszawa.

Cieszkowski Z., 2004, Ocena stopnia zaawansowania procesu modernizacji wiejskich sieci elektroenergetycznych na terenach ZEWT S.A. Analiza dla potrzeb opracowań planistycznych, COSiW SEP, II Ogólnopolska Konferencja ETW, Materiały Konferencyjne, Jachranka.

Krajowy plan działania w zakresie energii ze źródeł odnawialnych - dokument przyjęty przez Radę Ministrów 7 grudnia $2010 \mathrm{r}$.

National Renewable Energy Action Plan - document adopted by the Council of Ministers on 7 December 2010.

Krajowy Plan Rozwoju Mikroinstalacji Odnawialnych Źródeł Energii do roku 2030, 2015, Instytut Energetyki Odnawialnej, Warszawa.

National Plan for the Development of Micro-installations of Renewable Energy Sources until 2030, 2015, Institute of Renewable Energy, Warsaw.

Określenie potencjału energetycznego regionów Polski w zakresie odnawialnych źródeł energii wnioski dla Regionalnych Programów Operacyjnych na okres programowania 2014-2020, 2011, Instytut Energetyki Odnawialnej na zlecenie Ministerstwa Rozwoju Regionalnego, Warszawa. Determining the renewable energy potential of Polish regions - conclusions for Regional Operational Programmes for the period 2014-2020, 2011, Institute of Renewable Energy, commissioned by the Ministry of Regional Development, Warsaw.

Plan Zagospodarowania Przestrzennego Województwa Mazowieckiego - Uchwała Nr 22/18 Sejmiku Województwa Mazowieckiego z dnia 19 grudnia 2018 r. (Dz. Urz. Woj. Maz. z 2018 r. poz. 13180). Spatial Development Plan for Mazovia Province - Resolution No. 22/18 of the Sejmik of Mazovia Province of 19 December 2018. ( Journal of Law of Mazovia Province of 2018, item 13180).

Program możliwości wykorzystania odnawialnych źródeł energii dla Województwa Mazowieckiego, Uchwała Nr 208/06 Sejmiku Województwa Mazowieckiego z dnia 9 października 2006 r. Program of Renewable Energy Sources Opportunities for Mazovia Province, Resolution No. 208/06 of the Seimik of Mazovia Province of 9 October 2006. 
Strategia Rozwoju Województwa Mazowieckiego do 2030 roku. Innowacyjne Mazowsze - Uchwała Nr 158/13 Sejmiku Województwa Mazowieckiego z dnia 28 października 2013 r.

Development Strategy of Mazovia Province until 2030. Innovative Mazovia - Resolution No. 158/13 of the Sejmik of Mazovia Province of 28 October 2013.

Straty energii elektrycznej w sieciach elektroenergetycznych, Polskie Towarzystwo Przesyłu i Rozdziału Energii Elektrycznej, VIII konferencja naukowo-techniczna 21-22 marca 2018 r., Wrocław.

VIII scientific and technical conference, Losses of electricity in power grids 21-22 March 2018, Wrocław.

Ustawa z dnia 10 kwietnia 1997 r. Prawo energetyczne (Dz.U. z 2018 r., poz. 755 z późn. zm.). Act of 10 April 1997 - Energy Law and (Journal of Laws of 2018, item 755, as amended).

Ustawa z dnia 20 maja 2016 r. o inwestycjach w zakresie elektrowni wiatrowych (Dz.U. z 2016 r., poz. 961). Act of 20 May 2016 on investments in wind power plants (Journal of Laws of 2016, item 961).

Ustawa z dnia 22 czerwca 2016 r. o zmianie ustawy o odnawialnych źródłach energii oraz niektórych innych ustaw (Dz.U. z 2016 r. poz. 925).

The Act of 22 June 2016 amending the Renewable Energy Sources Act and certain other acts (Journal of Laws of 2016, item 925).

Ustawa z dnia 7 czerwca 2018 r. o zmianie ustawy o odnawialnych źródłach energii oraz niektórych innych ustaw (Dz.U. z 2018 r. poz. 1276).

Act of 7 June 2018 amending the Renewable Energy Sources Act and certain other acts (Journal of Laws of 2018, item 1276).

Ustawa z dnia 19 lipca 2019 r. o zmianie ustawy o odnawialnych źródłach energii oraz niektórych innych ustaw (Dz.U. z 2019 r. poz. 1524).

The Act of 19 July 2019 amending the Renewable Energy Sources Act and certain other acts (Journal of Laws of 2019, item 1524).

Translated by Wojciech Dąbrowski 


\section{Studium rozwoju mikroenergetyki prosumenckiej w subregionie siedleckim}

\section{STRESZCZENIE}

Opracowanie prezentuje wyniki badań $\mathrm{i}$ analiz przeprowadzonych $\mathrm{w}$ odniesieniu do najpopularniejszego obecnie segmentu energetyki odnawialnej, którą jest mikroenergetyka, rozwijana na najniższym poziomie całego cyklu wytwarzania, przesyłu, dystrybucji oraz konsumpcji energii, czyli na poziomie poszczególnych jej odbiorców. Jest ona istotnym składnikiem energetyki obywatelskiej, w której dotychczasowy konsument (osoba prywatna, jednostka samorządowa, podmiot gospodarczy itp.) staje się również producentem energii oraz czynnym partnerem sektora energetycznego w zarządzaniu energią na poziomie lokalnym, działaniu na rzecz poprawy efektywności wykorzystania energii, uzyskując z tego tytułu określone korzyści finansowe oraz energetyczne i środowiskowe.

W artykule przedstawiono rzeczowe efekty energetycznego wykorzystania zasobów OZE w segmencie mikroenergetyki elektroenergetycznej i cieplnej na obszarze subregionu siedleckiego (52 gminy - $16.5 \%$ ogółu gmin województwa mazowieckiego), co pozwoliło na zdobycie doświadczeń praktycznych umożliwiających rozszerzenie badań o inne subregiony województwa. Zbadano wpływ, jaki na rozwój mikroenergetyki lokalnej (na poziomie gminnym) wywarły krajowe uwarunkowania prawne oraz ustawowy system wsparcia, a także działania planistyczne i organizacyjne samorządu województwa mazowieckiego, jak również samorządów gmin. Przeanalizowano podstawowe uwarunkowania lokalne, w tym ekonomiczne (dochody gmin), techniczne (profile energetyczne gmin, stan sieci dystrybucyjnych), budowlane oraz środowiskowe. Zaakcentowano liczne uwarunkowania pozytywnie wpływające na rozwój segmentu, ale też wyraźnie wskazano na realne ograniczenia. Jako źródła informacji wykorzystano podstawowe akty prawne poziomu krajowego, dokumenty programowe, planistyczne oraz strategiczne poziomu regionalnego i gminnego, dane GUS oraz przedsiębiorstw energetycznych, informacje uzyskane z przeprowadzonej ankietyzacji gmin. W chwili obecnej brak jest jeszcze specjalistycznych, zilustrowanych konkretnymi danymi, wskaźnikami liczbowymi publikacji branżowych, dotyczących praktycznych efektów rozwoju tego segmentu energetyki na poziomie gmin województwa mazowieckiego. Niniejszy artykuł ma za zadanie wypełnienie tej luki. $\mathrm{Na}$ bazie przeprowadzonych analiz oraz najnowszych działań legislacyjnych i organizacyjnych rządu, zmierzających do ułatwienia rozwoju mikroenergetyki prosumenckiej, podjęto autorską próbę określenia realnego miejsca i roli tego segmentu elektroenergetyki w wypełnieniu krajowych celów wykorzystania OZE w perspektywie lat 2020-2030.

Słowa kluczowe: odnawialne źródła energii, prosument, polityka klimatyczno-energetyczna, mikroinstalacja, instalacja fotowoltaiczna, kolektor słoneczny, pompa ciepła

Zbigniew Cieszkowski, MSc Eng - a specialist in the area of electricity and renewable energy development, an employee of the Field Branch in Siedlce of the Mazovian Office for Regional Planning in Warsaw.

Zbigniew Cieszkowski, mgr inż. - specjalista w zakresie elektroenergetyki oraz zagadnień zwiq̨zanych z rozwojem odnawialnych źródeł energii, pracownik Oddziału Terenowego w Siedlcach Mazowieckiego Biura Planowania Regionalnego w Warszawie. 